Rev. Tadeusz Kasabuta University of Bialystok

\title{
The Influence of the Catholic Church in Cracow on the Cathedral Chapter of Vilnius from the Fifteenth through Eighteenth Centuries
}

Like the entire Diocese of Vilnius, the Cathedral Chapter of Vilnius drew considerably from the experience of the ecclesiastical environment of the Diocese of Cracow, which had already existed for four centuries when the Vilnius Chapter began and was establishing and organizing its own institutions and structures. Although the Diocese of Vilnius had remained part of the organizational structures of the ecclesial province of Gniezno from the beginning of the fifteenth century, it looked to Wawel and not to Wzgórze Lecha's example. From the fourteenth century onward, Vilnius and Cracow were the capital cities of the Polish-Lithuanian state. For this reason, it was fitting that both of the dioceses, including their cathedral chapters, were organized, looked, and functioned similarly. When the local Church was being established and organized in Lithuania, Cracow naturally served as a model for Vilnius because the local church in Cracow had already existed for more than four centuries and was, therefore, more organized, dynamic, and greatly exposed to the world in every respect than the ecclesiastical environment of Gniezno. This was also due to the fact that the Diocese of Cracow was at the center of royal power: it supported the throne of the Commonwealth directly; it sanctioned the court's actions; it provided the monarch with expert and intellectual help necessary to conduct internal politics and engage in diplomacy. It is also significant that the person responsible for establishing the Church in Lithuania was, in fact, Lithuanian—King Władysław II Jagiełło was the first Jagiellonian to ascend the Polish throne. His successors continued his policies in the religious realm in Lithuania. It is not surprising, therefore, the Jagiełłoes were solicitous to ensure that Vilnius enjoyed the proper place in the hierarchy of Polish-Lithuanian dioceses under their jurisdiction in accordance with the belief that "Vilnius 
History of the Church cannot stand out from Cracow."The Lithuanian King Władysław II Jagiełło provided materially for the Church in Vilnius, and he ensured that the capital of the Grand Duchy of Lithuania had the proper position within the structures of the Polish-Lithuanian state, which has becoming increasingly more integrated. Although the Diocese of Vilnius drew from the Diocese of Cracow's example, it did not blindly imitate it. After it had been established and organized, the Vilnius Cathedral Chapter was able to develop its own models, unique identity, and manner of functioning as a completely self-sufficient corporation that no longer needed to refer so strongly to the model of Cracow.

Key words: Catholic Church, Poland, Lithuania, Cracow, Vilnius, Diocese of Cracow, Diocese of Vilnius, cathedral chapter, cathedral, bishop, prelate, canon.

The topic to which the title of this article refers has been discussed very little in both Polish and Lithuanian historiography. In fact, one might argue that it has bot been discussed at all. This study was conducted with the awareness that the information that follows will pave the way for an area of history that is hardly known. The reader may be surprised to learn that institutions that played a significant role in the cultural, political, economic, and social landscape of the PolishLithuanian Commonwealth, which was, after all, one of the most powerful countries in Europe at the time, have not yet sparked the intellectual interest of specialists in this field. This does not mean that historians have not been interested at all in the canonical corporations of Cracow and Vilnius; for, the bibliography for this article is quite extensive. What historians have neglected, however, is to consider the mutual relationship between the two capitular chapters-Cracow, for the Crown, and Vilnius for the Grand Duchy of Lithuania-and how these two centers of ecclesiastical and, indirectly, state governance influenced each other. The lack of research in this area is crucial because it has prevented historians from coming to a more complete understanding of such a peculiar, unique, and dynamic political and cultural entity that was the relationship between Poland and Lithuania from the Kreva through Horodło and Lublin up to modern times. On an ecclesiastical level, Vilnius would not have been what it was without Cracow, just as Cracow cannot be fully understood apart from Vilnius. The Cathedral Chapters of Cracow and Vilnius were both established in radically different conditions. The canonical corporation of Cracow passed through all of the typical stages involved in the formation of cathedral chapters in the Latin Church in Western Europe. It began to function through the establishment of a monastic communal 
life (communis vita canonica), then monks and diocesan clergy (clerus regularis et saecularis) were included, and finally it was made up of diocesan clergy only. This community of clergy gave rise to the Cathedral Chapter of Cracow. ${ }^{1}$ With time, property was allocated to bishops and the chapter, which was then divided into prebends, and the internal organization of the chapter was established. The Benedictine monks were removed from the bishop's presbytery at Wawel and a Cracovian chapter made up of members of the diocesan clergy took its place at the end of the eleventh century. After ecclesiastical property was divided between the bishops and canons, and after the canonical goods were separated into prebends and common property, which was the custom at that time, the cathedral chapter began to operate in the modern sense of this term. One might rightfully ask at this point: What kind of rule regulated the common life of the oldest chapter of Cracow? According to Władysław Abraham, this rule can be found in Collectio tripartite, which is stored in the Cathedral Library in Wawel. The final edition of this collection dates back to the seventeenth century. The work is a systematic collection made up of three parts, the second of which contains legal treatises on ecclesiastical matters. All three parts are categorized according to people, things, and activities. ${ }^{2}$

The internal organization of the Cracow Cathedral Chapter took place over a long period of time and formally concluded in the second half of the fifteenth century with the following: dignitates (6) and canonici (30). ${ }^{3}$ Then the following order and ranks of prelate dignities was established: dean (1166), prepositor (1179), archdeacon (1166), scholastic (1166), cantor (1166), custodian (1166), and chancellor (1727). It is worth noting that the ranking of the prelate dignities was not determined definitively until the fifteenth century. In many of the previous catalogs, the archdeacon appears second (and not third), while the prepositor appears third.

This is a brief overview of how the Cathedral Chapter of Wawel was organized when the Diocese of Vilnius and its own cathedral chapter entered onto the historical scene in 1388. In that year, on March 12, Pope Urban VI issued the papal bull Romanus Pontifex. The pope appointed Bishop of Poznan, Dobrogost, as the executor of the determinations contained in the document, and there are many

1 C. J.von Hefele, Conciliengeschichte, Bd 4, Freiburg in Breisgau 1879, S. 9 u.folg.; W. M. Plöchl, Geschichte des Kirchenrechts, Bd 1, Wien 1959, S. 349-352.

2 W. Abraham, Organizacja Kościoła w Polsce do połowy wieku XII, (Poczatek biskupstwa i Kapituły katedralnej w Krakowie) (Poznań: 1962), 305-306. 
History of the Church

indications that the bishop carried out the papal orders that same year by establishing a chapter college in the newly erected diocese. The chapter was made up of two prelatures and ten canons. The two prelate dignities were: prepositor, which the document defined as "the first clerical dignity after the bishop," and dean, who had the right to appoint clergy (except canons) to carry out particular services in the cathedral. ${ }^{4}$ The process of establishing who made up the Cathedral Chapter of Vilnius took more than one hundred years. In chronological order, the following dignitates appeared: custodian (1397), archdeacon (1435), scholastic (1522), and cantor (1522). At this time, and certainly after 1502, two more canons arrived..$^{5}$ The final composition of the chapter was determined before 1525 , since twelve canons are listed in the records that year. ${ }^{6}$ Just like the Cracow Chapter, the ranking of the different groups of prelates came about naturally and was based primarily on the chronological order in which individual dignities were appointed. Like in Cracow, when multiple dignities were appointed at the same time, the importance of the functions as well as the will of the person who created the dignity determined the rank. Therefore, after the dignities of scholastic and cantor were established in 1522, the ranking of prelates was as follows: prepositor, dean, archdeacon, custodian, scholastic, cantor. On the other hand, just like in Cracow generally (but with a few exceptions) the precedence of the canons was based on their seniority. The longer a canon was part of the chapter, the higher was his position in it. ${ }^{7}$

Although none of the documents prepared by the Cathedral Chapter of Vilnius obliged the corporation to follow the model of the Cathedral Chapter of Cracow, it nevertheless gravitated toward following it from its inception, which the Vilnius Chapter openly admitted and outwardly demonstrated. It is important to note that, when the first to prelatures were created, the prepositor was given precedence, followed by the dean, which indicates that the chapter in Vilnius deviated from the chapter in Cracow's example in this instance. In Cracow, the dean

$4 \quad$ Kodeks dyplomatyczny katedry i diecezji wileńskiej (KDKDW), vol. 1, book 1, eds. J. Fijałek and W. Semkowicz (Kraków: 1948), 24-26.

$5 \quad$ J. Fijałek, "Kościół Rzymsko-katolicki na Litwie. Uchrześcijannienie Litwy przez Polskę i zachowanie w niej języka ludu pod koniec Rzeczpospolitej," in Polska i Litwa w dziejowym stosunku, Kraków 1914, s. 275-276.

6 Lietuvos Mokslu Akademijos Vrublevskiu Biblioteka [Wroblewski Library of the Lithuanian Academy of Sciences] (LMAB), f. 43-210, Acta Capituli Vilnensis (ACV), vols. 1-2 (1502-1546), k. 95.

$7 \quad$ Relationes status Dioecesium in Magno Ducatu Lithuaniae I:Dioeceses Vilnensis et Samogitiae, arr. P. Rabikauskas, (Romae: 1971), 202. 
was the head of the chapter, while the prepositor came second or third. According to the wishes of Bishop Dobrogost, the Cathedral Chapter of Vilnius followed the example of royal chapters (Poznań, Gniezno, Płock or Włocławek.) As more dignities were appointed, the Cathedral Chapter of Vilnius appointed the prepositor to the first place. This ranking endowed him with practically no rights or privileges. The dean, who was always appointed to the first place in Cracow and managed the entire corporation in practice, was appointed to the second place in Vilnius. In this regard, the reformation decree of 1596 that was issued after the Wawel Cathedral underwent a visitation concerns the scope of the dean's role. This document does not impose any new duties on the dean; instead, it simply recalls the duties that had already been determined and established legally long ago. The document clearly conveys that the dean had the most say in the Cracow Chapter:

The Dean... is first and presides over the chapter; he knows all of the prelates' duties, the norms of canon law, and the constitutions of provincial and diocesan synods. He proposes to the cathedral chapter what pertains the growth and beautification of divine service, discipline, and good customs among the cathedral clergy and their life in common, as well as the administration of earthly goods. He has the right to express his judgment first, accept the opinion of others, draw conclusions, and recommend that they be implemented. He is also responsible for pastoral care in the cathedral, due to which he has the duty to supervise pastoral activities. He must also oversee the administration of the holy sacraments. It is his duty to ensure that the choir prayers take place in the prescribed order. ... As the head of the cathedral presbytery, he has the power to institute vicars, to admonish them, and to deprive them of their benefits if they are disobedient. ${ }^{8}$

When comparing this decree with a similar passage from a document confirming the privileges of the Vilnius Chapter that was written by the papal legate Bernardo Bongiovanni around the same period (1561), it is clear that the competences required of the deans of both chapters are completely identical. To be clear, Bongiovanni's document on the dean's duties and powers clearly states "ut habet Decanus Ecclesiae Cracoviensis, ad cuius exemplum Vilnensis Ecclesia fundata est [as a dean of the Cracovian Church, on whose example Vilnius Church was founded]." In English, the text explaining the dean's duties reads:

[The Dean-auth.] must ensure the proper order of divine worship in the cathedral. He should ensure that its mansionaries, chaplains, altarists, and other clergy, especially the chapter vicars, seminarians,

8 Statuta capitularia Ecclesiae Cathedralis Cracoviensis, ed. I. Polkowski (Cracoviae: 1884$), 245$. 
History of the Church

and students of the cathedral school, perform their functions at the prescribed time and in the prescribed order in the temple of the cathedral, as well as all of its chapels, in the choir, during processions, and in other locations. [...] He must oversee that the proper chanting and music is sung in the cathedral and exercise complete authority over the vicars. He has other duties that are the same as the dean of the Cracovian Church, on whose example the Vilnius Church was founded. ${ }^{9}$

These are no more and no less the competences of the dean, the first in dignity in the Cracow Chapter.

What, then were the duties of the prepositor-the prelate who was ranked first in dignity in the Cathedral Chapter of Vilnius? Unfortunately, no normative or other acts elaborate specifically on this subject. The duties of the prepositor of the Cathedral Chapter of Vilnius essentially came down to the fact that he was ranked first, and his only task was to wait for an opportune episcopal vacat (vacancy). However, in the eighteenth century, almost every Vilnius prepositor was a titular bishop. An interesting characteristic of Vilnius Cathedral Chapter was the fact that, in the second half of the seventeenth century and throughout the eighteenth century, the first prelate in dignity-the preposit-was rarely present at sessions, even general ones, and he appeared even less often in the choir and at processions, despite the fact that he lost his refection because of this. The protocols of ordinary and extraordinary sessions and lists that meticulously record the amounts of refections allocated prove this. Even more puzzling is the fact that prepositor was not reprimanded or otherwise admonished for this. It is evident his presence did not contribute much to the chapter, and his absence was not a hindrance. ${ }^{10}$ Generally speaking, what the prepositor of Vilnius was known for was simply being part of the chapter and being ranked "first," whatever that meant. Similarly, the prepositor of the Cracow Cathedral Chapter had little to say. In that chapter, however, he was assigned to only the second or third choir stall, which was a much more modest position than his Vilnius counterpart enjoyed. The Cathedral Chapter of Cracow's statutes do not give him much of a role. It appears that, up until the sixteenth century, candidates for this prelature were not even required to be ordained

9 Rev. J. Kurczewski included the royal privilege granted in 1558 and the document of the papal legate from 1561 in his work Kościót zamkowy czyli katedra wileńska, cz. 2 (Wilno: 1910), 77-80.

10 LMAB, f. 43-673, Percepta masae (...) Cap. Vilnensis pro consolationibus et omnibus obventionibus, 1685-1686, k. 4; LMAB, f.43-1128, Rozdziat refekcyjnej summy, 1791-1792, k. 1 . 
priests. ${ }^{11}$ The rights given to the other prelates of both of the chapters were almost identical.

It is also worthwhile to consider more closely something that was equally important to both chapters - namely, their statutes. These statutes consisted of twenty-four paragraphs that the bishops granted to the Cracow Chapter from its inception. The Cracow Chapter accepted and implemented these statutes at the session held on May 12, 1356. In the fourteenth and fifteenth centuries, the chapter added an additional History of the thirty-eight points, while the bishops added another twelve points to the statutes. By the middle of the fifteenth century, the statutes consisted of a total of seventy-four points, which were written up into a first edition between 1467-1468. ${ }^{12}$

When the Cathedral Chapter of Vilnius was being established, it did not have any privileges or land grants. Instead, it supported itself exclusively from the Bishop of Vilnius' mensa. At that time, the Cathedral Chapter of Cracow already had codified statutes, upon which the canonical corporation of Cathedral Chapter of Vilnius was organized and systematized, and this was sufficient for a time. Later, however, the Vilnius Chapter began to be more independent, started to give its own privileges and grants, and sought stronger legal legitimacy. This became all the more necessary because, after the first bishop of Vilnius, Andrzej, died in 1398, the Vilnius Chapter elected and preconized Bishop Jakub Plichta to take his place on May 5, 1399. Even before the newly elected bishop's ingress, the chapter hurried to him with acts documenting its privileges and a text containing six postulates, which could be described as statutes in the terminology of that time. Without going into detail, it is sufficient to say that the postulates did not concern essential matters regarding the chapter's organization or systematization. ${ }^{13}$ Why, especially when it would seem that the postulates concerned issues that would necessitate the establishment of the chapter's legal basis? There can be only one answer: the Vilnius Chapter did not see such a need because both politically and organizationally it was still following successfully the proven norms constituting the Cathedral Chapter of Cracow. The relationship between

11 Kodeks dyplomatyczny katedrykrakowskiejśw. Wacława, vol2, ed.F.Piekosiński, no 476, (Kraków: 1883), 287-291; Statuta capitularia, 246.

12 "Statuta Capituli Ecclesiae Cathedralis Cracoviensis A. 1328-1478 Sbignei cardinalis et episcopi Cracoviensis statutum," ed. H. Heyzmann, in Staropolskie Prawa Polskiego Pomniki, vol4(Kraków 1875), 115-170; Statuta capitularia Ecclesiae Cathedralis Cracoviensis mandato et impensis C. Teliga, ed. I. Polkowski (Cracoviae: 1884).

13 KDKDW, no. 35, 63-64. 
History of the Church

the Cathedral Chapter of Vilnius as a corporation and its individual members with regard to the ordinary bishop and the scope of both authoritative entities' rights and competences were based on the already-established and well-prepared rights of the Cracow Chapter.

More important than the actual content of the statutes was the fact that this was the first instance where the Vilnius Chapter referred to the Cracow Chapter's statutes and conferred with the bishop by presenting to him so-called "points," meaning postulates, suggestions, or questions pertaining to current issues that required the cooperation of both decision-making diocesan bodies-the bishop and the chapter. Over time, this practice became a law that was implemented in the Dioceses of Vilnius and Cracow until the end of the eighteenth century.

As contentions and conflicts between the bishop and the chapter arose, both sides were forced to compromise. The statutes of the Cathedral Chapter of Cracow were unable to provide solutions to the political and socioeconomic realities of the Grand Duchy of Lithuania. For this reason, the Vilnius Chapter expressed more frequently and persistently its need to codify its rights, customs, duties, and privileges.

It is no coincidence that the first edition of the Cathedral Chapter of Vilnius' statutes was created at the beginning of the sixteenth century. The statutes were most likely prepared as the Vilnius community's response to the announcement that the Cracow chapter had prepared its first codex of statutes (1467-1468); from that moment forward, the bishops of Vilnius, beginning with Jan Eosowicz, insisted that the chapter begin working on recording its own statutes, and then intensely mobilized the chapter in every way by requests and even threats to complete the endeavor. The collection of statutes was certainly ready before 1515. In 1518-one year after the closing of the Fifth Lateran Council, Bishop Wojciech Radziwiłł approved and promulgated the statutes in the diocese. By the end of 1520, Pope Leo X confirmed the statutes through his legate, the Titular Bishop of Gardien Zacharias Ferreri. ${ }^{14}$ At that time, all of the grants and privileges that were given to the chapter, particularly the papal privileges, were approved: "[I] $\mathrm{n}$ this particular regard, the Church of Vilnius and the Chapter were

$14 \quad$ LMAB, f. 43-152, Summa Privilegiorum, Immunitatis, Exemptionum, Libertatum ceterarum eiusmodi Gratiarum in rem ac favorem Status Spiritualis et respective Cathedrae Vilnensis eiusque Illmi Capituli servientium, ex ipsis originalibusad promtiorem notitiam: Confirmatio omnium privilegiorum et Immunitatum exemptionum statutorum venerabile capitulo Vilnensi servientium per Zachariam episcopum Gardiensem ad regnum Poloniae et M. Ducatus Lituniae nuntium apostolicum facta a. 1520 gris 29 d., k. 3. Fr. J. Kurczewski reprinted this document in extensor, see J. Kurczewski, Kościót zamkowy, cz. 2 (Wilno: 1910), 35-37. 
compared with the Cracow bishopric in its complete and free jurisdiction and possession of power over vicars, mansionaries, altarists, meaning all chaplains and clerics that belonged to this same Vilnius Church." By virtue of the Holy See's decision, the curators of the Vilnius Chapter were appointed bishops of Cracow and Euck" so that "people or the entire Vilnius Chapter would always stand in defense of all of these rights and provide the necessary help." 15 The minutes of both the ordinary and extraordinary sessions of the Cathedral Chapter of Vilnius reveal that, after the first statutes were codified but did not contain statutory sanctions to resolve issues when disagreements and contentions arose, the chapter referred to the Cracow statutes, a copy of which was available in the chapter house, and then obtained the files that documented their own privileges in the archives.

Cracow's influence on the Vilnius Chapter is also evident in less important matters. For example, a breviary from that time reveals that, in 1634, Pope Urban VIII granted the Cracow Chapter the privilege of wearing a rochet, mantelletta, and Roman cope during liturgical and official rites on September 13. Upon learning about this, the Vilnius chapter began to strive for the same privileges and ultimately received them in 1649-that is, fifteen years after the Cracow Chapter. ${ }^{16}$ Since the Vilnius canons initially were not sure about which rights to which they were entitled and the corresponding duties, and since they had differing opinions regarding how to interpret the privileges, they resorted to the same solution-namely, in May 1653, the cathedral's master of ceremonies was ordered to copy the relevant provisions from the Cracow Chapter's files and place them in a visible location in the canon sacristy. In this way, as the chapter session minutes indicate: "if someone does not know something, let him go and read, so that he does know and does not clamor in vain." 17

Texts documenting this privilege and legal acts in which the Holy See inspired the decision to distinguish first the Cracow Chapter and later the Vilnius Chapter with special attire shed a great deal of light on the ecclesiastical relationship between Cracow and Vilnius. In this regard, one such document states:

We have learned that in the city of Cracow, which is the capital of the Polish Crown and the famous abode of kings, princes, magnates, and eminent men who come and reside there, and that Cracow is the necropolis of many Saints and Blesseds, and that there are royal tombs

\footnotetext{
15 LMAB, f.43-152, Summa Privilegiorum, k. 3.

16 LMAB, f.43-220, ACV, vol. 12 (1644-1652), 169.

17 LMAB, f.43-221, ACV, vol. 13 (1652-1663), k. 82.
} 
History of the Church in Cracow ... that kings often visit Cracow in order to participate in Holy Mass and the Divine Liturgy, and that numerous state dignitaries and princes follow after them, the cathedral of Cracow has become a place where many meetings take place and, for this reason, its canons deserve more honor and glory than other chapters .... Therefore, we to whom Polish King Władysław has also addressed a request in this matter wish to show our respect to this Chapter with special signs of reverence ... We have decided to grant the requests of this Chapter and pronounce that it, its canons, and their successors have the perpetual privilege to wear the cope, rochet, and mantelletta like the Chapter and canons at St. Peter's Basilica in Rome, who wear [these vestments] during solemnities, liturgical functions, and public acts. ${ }^{18}$

When comparing this act to the analogous document issued for the Vilnius Chapter, it is clear that the parts of the text that substantiate the decision to grant this privilege are almost identical. In both documents, the phrase "the cathedral of Cracow [Vilnius - 1649] has become a place where many meetings take place and, for this reason, its canons deserve more honors and glory than other chapters" is used. In the document for Vilnius, however, the words: "than other Lithuanian chapters" were added. ${ }^{19}$

The Vilnius Chapter's coat of arms was also significant. The coat was based on the "Aaron" coat of arms, which depicts three gold princely crowns in a 2-1 arrangement set against a blue field, taken directly from the Cracow Chapter, and used for the first century and a half of the Vilnius Chapter's existence. ${ }^{20}$ It was not until the mid-sixteenth century that the Vilnius Chapter changed the coat of arms by adding a golden-colored, two-armed Jagiellonian cross (also called the Anjou) while keeping the other essential elements. Two crowns were arranged symmetrically on both sides of the cross, while the third was moved outside of the heraldic shield and placed on a jewel. Over time, an element from the "Jończyk" coat of arms was added-namely, the bottom half of the cross was partially split down the middle. ${ }^{21}$ The Cracow

18 Archives of the Metropolitan Curia in Cracow, Acta Episcopalia, vol. 48 (Acta actorum, institutionum R.D. Jacobi Zadzik, episcopi Cracoviensis ducus Severiae ab 8 Februarii 1636 - 20 Decembri 1638), kk. 82-84. This text was obtained, translated, made accessible, and analyzed by Fr. B. Kumor in Dzieje diecezji krakowskiej do roku 1795, vol. 2 (Kraków: 1999), 334.

LMAB, f. 43-220, ACV, vol. 12 (1644-1652), 169.

K. Niesiecki, Herbarz Polski, vol. 1, ed. J. N. Bobrowicz (Lipsk: 1839-1845), 45. zamkowy, 314 . 
Chapter's coat of arms, on the other hand, has remained unchanged to this day.

The question remains: Why did the Vilnius Chapter refer so much to Cracow and not to another diocese such as the Metropolitan Archdiocese of Gniezno when organizing itself. The answer is simple but worth recalling: both Vilnius and Cracow were capital cities. Therefore, it was appropriate that both dioceses, including their cathedral chap-

ters functioned, if not identically, then comparably, and this of course included their prestige and splendor. Cracow served as a natural model because its local church environment had already existed for almost four centuries when the Church in Lithuania was being organized. Another fact to consider is that King Władysław II Jagiełło was responsible for establishing the foundations for the Church in Vilnius, and his Jagiellonian successors continued his policies. They ensured that Vilnius was given the proper place within the hierarchy of the diocese in the lands under their rule in accordance with the principle: "Vilnius cannot stand out from Cracow." Jagiełło and his successors financially supported both the bishop of Vilnius and the Cathedral Chapter of Vilnius and remained their legal patrons. Compared to the royal cathedral chapters, Jagiełło's had incomparably more influence on the designation of prebends; he conferred as many as three prebends to prelates, meaning half of all the prelature prebends, and all twelve of the prebends to canons, which was eighty percent of the prebends of the entire chapter. For comparison, in Cracow the king had the rights of gifts and patronage for two prelatures and one canon, which was slightly more than eight percent of all prebends. The bishop of Cracow had the decisive voice when it came to gifting prelatures and canons, which his Vilnius counterpart could only envy.

The fact that the Cathedral Chapter of Vilnius drew from the Cathedral Chapter of Cracow's experience does not mean that it blindly and uncritically imitated Cracow. Once it had become established, the Vilnius Chapter was able to develop its own models and unique identity, and it could function as a completely self-sufficient corporation. It ceased to refer so extensively to the model of Cracow. This, however, is a different topic that must be treated separately and more extensively.

\section{Bibliography}

\section{Archival Sources}

1. Lietuvos Mokslų Akademijos Vrublevskiu Biblioteka (LMAB)- Lithuanian Academy of Sciences Vrublevskis Library 
History of the Church

2. Acta Capituli Vilnensis, vols. 1-2 (1502-1546), f. 43-210.

3. Acta Capituli Vilnensis, vol. 12 (1644-1652), f. 43-220.

4. Acta Capituli Vilnensis, vol. 13 (1652-1663), f. 43-221.

5. Percepta masae (...) Cap. Vilnensis pro consolationibus et omnibus obventionibus (1685-1686), f. 43-673.

6. Rozdziat refekcyjnej summy (1791-1792), f. 43-1128.

7. Summa Privilegiorum, Immunitatis, Exemptionum, Libertatum ceterarum eiusmodi Gratiarum in rem ac favorem Status Spiritualis et respective Cathedrae Vilnensis eiusque Illmi Capituli servientium, ex ipsis originalibusad promtiorem notitiam: Confirmatio omnium privilegiorum et Immunitatum exemptionum statutorum venerabile capitulo Vilnensi servientium per Zachariam episcopum Gardiensem ad regnum Poloniae et $M$. Ducatus Lituniae nuntium apostolicum facta a. 1520 bris 29 d., f. 43-152

\section{Archives of the Metropolitan Curia in Cracow}

1. Acta Episcopalia, vol. 48 (Acta actorum, institutionum R. D. Jacobi Zadzik, episcopi Cracoviensis ducus Severiae ab 8 Februarii 1636 - 20 Decembri 1638).

\section{Printed Sources}

1. Kodeks dyplomatyczny katedry i diecezji wileńskiej, Tom 1, Zeszyt 1. Edited by J. Fijałek and W. Semkowicz, Kraków: 1948.

2. Kodeks dyplomatyczny katedry krakowskiej św. Wacława, Tom 2. Edited by F. Piekosiński. Kraków: 1883.

3. Monumenta Poloniae Vaticana, Tom 1. Kraków: 1913.

4. Relationes status Dioecesium in Magno Ducatu Lithuaniae I: Dioeceses Vilnensis et Samogitiae. Arranged by P. Rabikauskas. Romae: 1971.

5. Statuta capitularia Ecclesiae Cathedralis Cracoviensis mandato et impensis C. Teliga. Edited by I. Polkowski. Cracoviae: 1884.

6. Statuta capitularia Ecclesiae Cathedralis Cracoviensis. Edited by I. Polkowski. Cracoviae: 1884.

7. "Statuta Capituli Ecclesiae Cathedralis Cracoviensis A. 1328-1478 Sbignei cardinalis et episcopi Cracoviensis statutum." Edited by H. Heyzmann, 115-170. In Staropolskie Prawa Polskiego Pomniki, Tom 4. Kraków: 1875.

\section{Studies}

1. Abraham, W. Organizacja Kościoła w Polsce do połowy wieku XII (Poczatek biskupstwa i Kapituty katedralnej w Krakowie). Poznań: 1962.

2. Fijałek, J. “Kościół Rzymsko-katolicki na Litwie. Uchrześcijannienie Litwy przez Polskę i zachowanie w niej języka ludu pod koniec Rzeczpospolitej." In Polska i Litwa w dziejowym stosunku, 37-333. Kraków: 1914.

3. Hefele, C. J. Conciliengeschichte, vol. 4. Freiburg in Breisgau: 1879.

4. Kumor, B. Dzieje diecezji krakowskiej do roku 1795, vol. 2. Kraków: 1999

5. Kurczewski, J. Kościót zamkowy czyli katedra wileńska Cz. 2. Wilno: 1910. 
6. Niesiecki, K. Herbarz Polski, Tom 1. Edited by J. N. Bobrowicz. Lipsk: 1839-1845.

7. Plöchl, W. M. Geschichte des Kirchenrechts, Volume 1. Wien: 1959.

8. Znamierowski, A. Herbarz rodowy. Warszawa: 2004. 